UDC 811.111:81'27

DOI https://doi.org/10.32838/2710-4656/2021.1-2/20

Kurylenko D. .

Polissia National University

\title{
MOTIVATION AS AN INTERPRETATION \\ OF THE LINGUISTIC PICTURE OF THE WORLD: ASPECTS OF THE LEARNING ENGLISH LANGUAGE
}

The article deals with the concept of "motivation" and "linguistic picture of the world" is interpreted through the prism of present-day realities in the study of English as a background, which is implemented identically to the universe in the realization of a foreign language as a means of communication, fixation and self-presentation.

The purpose of the article is to define and implement motivation as an interpretation of the linguistic picture of the world in the process of learning English.

Tasks and goals. The study of motivation as an interpretation of the linguistic picture of the world is important for the reception and integration of the individual into the intercultural continuum, the actualization of his worldview and reflection on the existence of language as a sphere of thinking and transformation of consciousness.

The article systematically interprets and explores the concept of "motivation" and "linguistic picture of the world" through the prism of today's realities in the study of English as a background, which is implemented identically to the universe in the implementation of English as a means of communication, fixation and self-presentation.

Research methods. Hypothesis; data analysis to identify modern realities in the discourse of learning English; constructive method for the objective analysis of the phenomenon of inspiration in the modern paradigm of learning and reception of the English language.

Results of the research. The concept of "motivation" and "linguistic picture of the world" is interpreted through the prism of today's realities in the study of English as a background, which is realized identically to the universe in the implementation of a foreign language as a means of communication, fixation and self-presentation.

Conclusions. It should be summarized that the interpretation of motivation and language picture of the world are not just identical and interconnected, but moreover, these categories convert the sign "equal" through the realization of language goals, objectives and the end result in learning English as an attribute of life in today's reality.

Key words: language, eidos mentality code, motivation, determination, linguistic picture of the world, universe.

Introduction. Language is a mirror that is between the world and man, through which we can know the permanent properties of the universe. Motivation and determination of the linguistic picture of the world realize the eidos mentality code and the reception of the English language as a zeitgeist of existence in the polyphony of today. Especially relevant is the study of English as a means of communication and realization of personality.

The National Linguistic Picture of the World (NLPW) is "an interpretation verbalized by the language society and the worldview of the ethnos, the surrounding world and oneself in this world" $[6$, p. 6]. I. Golubovska notes that different language levels are able to objectify different types of conceptualization of reality (receptive, conceptual, emotional, value) [6, p. 25]. Cognitive activity "orients a person to build their own linguistic picture of the world, which is the basis for its rational and conscious behaviour" [10, p. 57]. Linguistic behaviour is a motivated action, respectively the inspiration in learning English is the key to understanding the existence of language.

Interpretation of the linguistic picture of the world through the paradigm of learning English in the coordinate system of scientists

Interpretation of the linguistic picture of the world is urgent in the study of English. Not surprisingly, the receptive paradigm of learning a foreign language (in the presented context - English) is an integral part of the objectification of oneself as a carrier of multicultural qualities in the system of "World-Me". M. Heidegger rightly remarked and defined language as a form in which man discovers himself in the world and discovers the world in himself. M. Heidegger 
interpreted language as a way for a person to accept the world ("as the abode of being") [5, p. 53]. Thus, each language unit is focused on the conceptual space of the environment; it becomes a speech manifestation of one or another of its fragments [3, p. 53]. V. Postovalova emphasizes: "The picture of the world is not a mirror image of the world and is not an open "window" into the world, namely a picture, i.e. interpretation, an act of worldview... it depends on the prism through which the worldview is realized" [11, p. 55]. L. Danylenko aptly emphasized that the philosophical doctrine of V. von Humboldt about the spirit of the people and the internal form of language as an expression of individual, original worldview is considered to be a thorough theoretical source of the fundamental problem of the relationship between language, culture and thinking [7, p. 3]. V. von Humboldt permanently emphasized the inseparability of the concepts of "language" and "people", "language" and "culture" [7, p. 38]. V. Zhayvoronok objectifies the etymology of the phenomenon and defines the picture of the world as follows: “... as a system of phonetic phenomena, lexicalsemantic and grammatical meanings, as well as stylistic characteristics", which "reflects the relatively objective state of the environment and inner world of a person" $[9$, p. 26].

G. Brutian reflects the linguistic picture of the world as "... knowledge enshrined in the words and phrases of a particular spoken language" [4, p. 109]. In O. Selivanova's scientific work "Modern Linguistics: Terminological Encyclopedia" the linguistic picture of the world is defined as "representation of objects, phenomena, facts, situations of reality, values, life strategies and scenarios of behaviour in language signs, categories, speech phenomena, which is a semiotic result conceptual representation of reality in ethnic consciousness" [12, p. 365]. T. Alisova argues that language has a body and spirit [2, p. 15]. The body is material, which we can see and hear, and the spiritual is hidden in the depths of historicaletymological and lexical-semantic labyrinths and national-cultural features of the ethnos. Material is amenable to study; the spiritual is passed from generation to generation on a mental-cognitive level and is quite difficult for members of a foreign ethnic group to perceive [2,p. 15]. Thus, the linguistic picture of the world is not only a way of self-presentation and self-realization, but also a means and an integral attribute that helps to comprehend, understand, interpret linguistic imperatives through the prism of personality, combine the past and produce it in the picture of the future.
Motivation as a component of the linguistic picture of the world in the study of English

The realization of language is impossible without the aspect of motivation, in fact. Every conscious individual tends to the initial enthusiasm, that is, motivation, without which the study of English is impossible. Seme "motivation" is used in modern psychology in a binary sense: as something that denotes a system of factors that determine behaviour (this includes, in particular, needs, motives, goals, intentions, aspirations and more) and as a characteristic of the process that stimulates and maintains behavioural activity at a certain level [8]. Motivation is a system of compulsions that determine the activity of the organism and determine its direction. Motivation explains the purposefulness of action, organization and stability of holistic activity addressed to achieve a specific goal. Thus, motivation is a comprehensive component of the worldview and reception of the linguistic picture of the world in the study of the English language. T. Alekseenko defines the concept of motivation as a dynamic category that contains not only motives but also needs that determine the behaviour of the individual in a social situation and to some extent can be defined as willingness to act in a certain way to achieve the goal based on understanding the value of success and assessment of their own abilities and efforts that need to be made for this, in their entirety $[1$, p. 6]. Motivational projections of learning English in higher education institutions include:

1. Unlimited access to information.

2. Satisfaction of own ambitions.

3. The desire for self-development.

4. Ability to communicate with foreign speakers.

5. No language barrier.

6. Opportunity to study and work abroad.

7. Successful self-realization in the chosen field.

English language in the educational context is dominant in the diversity of languages. Analyzing the factors of English popularity among students, researchers from different countries single out the dominance of English as a lingua franca, due to "total globalization into a holistic economic system, united not only by international division of labour, but also huge global production and sales structures, global financial system and information system on a planetary scale" $[13$, p. 415$]$

It is worth noting that learning English requires not onlymotivation, but the formation of a linguistic picture of the world. Anthropocentrism in this context appears as a component of the paradigm of the language system. Fixation of an individual's experience is verbalized 
at all levels of language, therefore, according to R. Grzegorczykova, the components of the linguistic picture of the world cover various linguistic aspects: grammatical properties of language, vocabulary, word formation, etymology, semantic connotations, literary texts, etc. [14, p. 45-47]. Of course, it should be noted that the fixation of language units at the level of existence is converted through the prism of one's own life experience and background, which appears as a universe in the study of a foreign language as a means of communication, fixation and realization of language as a system of existence, therefore, the researcher J. Machkevych states: "The distinction between non-verbalized and verbalized categories of human thinking is related to the distinction between the conceptual and linguistic image of the world. The conceptual image of the world is richer than the linguistic one, because different types of thinking cooperate in its creation, not only linguistic thinking" $[15$, p. 57]. Thus, the linguistic picture of the world is one of the layers of the general picture of the world and can be presented as a set of knowledge about the world, fixed in language.

Conclusions. In general, it should be emphasized that the interpretation of motivation and language picture of the world are concepts not just identical and interconnected, but moreover, these categories convert the sign "equal" through the realization of language goals, objectives and end result in learning English as an attribute of life in today's reality.

\section{References:}

1. Алексеєнко Т. Ф. Мотивація соціальної поведінки та механізми їі формування. Соціальна педагогіка: теорія та практика. 2011. № 4. С. 4-10.

2. Алисова Т. Б. Ономастологический подход при сопоставительном изучении лексико-семантических структур двух языков. Серия «Филологическая». 2005. № 3. С. 46-50.

3. Бацевич Ф. С. Філософія мови: Історія лінгвофілософських учень : підручник. Київ, 2008. 240 с.

4. Брутян Г. А. Язык и картина мира. Науч. докл. высши. шк. Философ. науки. 1973. № 1. С. 108-111.

5. Гайдеггер Мартін. Дорогою до мови. Львів, 2007. 232 с.

6. Голубовська I. О. Етнічні особливості мовних картин світу. Київ, 2004. 284 с.

7. Даниленко Л. Лінгвістика XX - початку XXI ст. у пошуках цілісної теорії взаємозв'язку мови, культури і мислення. Мовознавство, 2009. № 5. С. 3-11.

8. Додонов Б. Й. Логико-символическая модель мотивационной структуры деятельности. Новые исследования в психологии. 1974. № 1. С. 75-89.

9. Жайворонок В. В. Мова і духовний розвиток народу. Мовознавство. 1999. № 3. С. 22-30.

10. Копусь О. А. Роль концептуального аналізу художнього твору у формуванні текстової компетентності майбутніх учителів української мови і літератури. Наука і освіта. 2015. № 2. С. 56-62.

11. Постовалова В. И. Картина мира в жизнедеятельности человека. Роль человеческого фактора в языке: Язык и картина мира. Москва. 1988. С. 8-69.

12. Селіванова О. Сучасна лінгвістика: термінологічна енциклопедія. Київ. 2006.716 с.

13. Хоменко О. В. Мова міжнаціонального спілкування як економічна категорія. Педагогіка вищої та середньої школи. 2013. Вип. 37. С. 414-418.

14. Grzegorczykowa R. Pojęcie językowego obrazu świata. R.Grzegorczykowa. Jezykowy obraz swiata: praca zbiorowa pod red. Jerzego Bartminskiego. Lublin. 1990. P. 4-50.

15. Maćkiewicz J. Kategoryzacja a językowy obraz świata. J. Maćkiewicz. Językowy obraz swiata: praca zbiorowa pod red. Jerzego Bartminskiego. Lublin. 1990. P. 51-60.

\section{КУрИЛеНКО Д. В. МОТИВАЦІЯ ЯК ІНТЕРПРЕТАЦІЯ МОВНОЇ КАРТИНИ СВІТУ: АСПЕКТИ ВИВЧЕННЯ АНГЛІЙСЬКОЇ МОВИ}

Мова - дзеркало, яке знаходиться між світом і людиною, за допомогою якого ми можемо пізнати перманентні властивості універсуму. Мотивація та детермінація мовної картини світу зреалізовують код ментальності ейдосу та рецепції англійської мови як иайтіайсту буття в поліфонії сьогодення. Особливо актуальним є вивчення англійської мови як засобу комунікації та реалізації персоналії.

Інтерпретачія мовної картини світу повсякчас актуальна у вивченні англійської мови. Недарма рецептивна парадигма вивчення іноземної мови (у изьому контексті-англійської) є невід'ємною ланкою об 'єктивації себе як носія полікультурних якостей у системі «світ-я».

Мотивація як складова ланка, система спонукань зумовлює активність організму $і$ визначає ї̈ спрямованість. Мотивація пояснює циілеспрямованість діï, організованість $і$ стійкість цілісної активності, адресованої щуодо досягнення конкретної мети. Отже, мотивація - всеосяжний складник світобачення та рецепції мовної картини світу саме у вивченні англійської мови. 
Варто зауважити, що вивчення англійської мови потребує не лише мотивачії, а формування мовної картини світу. Антропоцентричність у изому контексті постає як складник парадигми мовної системи. Фіксація досвіду індивіда вербалізується на всіх рівнях мови.

Отже, варто підкреслити, щзо інтерпретація мотивації та мовної картини світу є поняттями не просто тотожсими та взаємопов 'язаними, ба більще, иі категорії конвертують знак «дорівнює» крізь реалізацію мовних иілей, завдань та кінцевого результату у вивченні англійської мови як атрибуту буття у сьогоденній реальності.

Мета статті полягає у визначенні та реалізації мотиваџї як інтерпретації мовної картини світу у проиесі вивчення англійської мови.

Завдання та цілі. Дослідження мотиваиії як інтерпретачії мовної картини світу є важливим для рецепиії та інтеграції індивіда в міжкультурний континум, актуалізаиії його світосприйняття та рефлексії побутування мови як сфери мислення та трансформаиії свідомості.

У статті системно інтерпретуються поняття «мотивація» та «мовна картина світу» крізь призму сьогоденних реалій у вивченні англійської мови як бектраунду, який зреалізовано тотожно до універсуму в реалізації іноземної мови як засобу комунікації, фіксації та самопрезентації.

Основні методи дослідження - гіпотеза; аналіз даних для виявлення сучасних реалій у дискурсі вивчення англійської мови; конструктивний метод задля об'єктивного аналізу феномена інспірації у сучасній парадигмі вивчення та рецепиії англійської мови.

Результати дослідження. Інтерпретовано поняття «мотиваџія» та «мовна картина світу» крізь призму сьогоденних реалій у вивченні англійської мови як бектраунду, який зреалізовано тотожно до універсуму в реалізації іноземної мови як засобу комунікації, фіксації та самопрезентації.

Висновки. Варто резюмувати, щьо інтерпретація мотивації та мовної картини світу є поняттями не просто тотожсним та взаємопов'язаними, ба більше, иі категорії конвертують знак «дорівнює» крізь реалізацію мовних иілей, завдань та кінцевого результату у вивченні англійської мови як атрибуту буття у сьогоденній реальності.

Ключові слова: мова, код ментальності ейдосу, мотивація, детермінація, мовна картина світу, універсум. 